\title{
MENUMBUHKAN SIKAP PEDULI SOSIAL PADA LINGKUNGAN SEKOLAH
}

\author{
Aisyah Nur Sayidatun Nisa, Noviani Achmad Putri, Fredy Hermanto, Asep \\ Ginanjar $^{\bowtie}$
}

Social Science Education Department, Faculty of Social Science, Universitas Negeri Semarang, Indonesia

\section{Info Artikel}

Sejarah Artikel:

Disubmit Oktober 2020

Direvisi: November 2020

Diterima: November

2020

Keywords:

Environmental arrangement,

Conservation Care for the

environment.

\begin{abstract}
Abstrak
Pengabdian ini diharapkan dapat membantu memberikan kontribusi terhadap kebermanfaatan lingkungan sekolah dan penumbuhan karakter konservasi peduli lingkungan. Sehingga dengan memanfaatkan lingkungan yang masih belum diberdayakan di SDN Patemon 2, mampu untuk mendukung pembelajaran nantinya. Pengabdian ini dilakukan dengan tahapan perencanaan, pelaksanaan dan evaluasi kegiatan yang menitikberatkan kegiatan menggunakan metode demonstrasi. Pengabdian berjalan dengan lancar dan mendapatkan respon yang baik dan luar biasa dari mitra, baik dari pihak sekolah maupun paguyuban wali murid kelas 2 terkait dengan penataan lingkungan SDN Patemon 2 dengan membuat taman ramah anak. Pengabdian ini juga memiliki target capaian yaitu berupa artikel capaian accepted. Selain itu, luaran tambahan dalam pengabdian ini adalah draft book chapter.
\end{abstract}

Email: aisyah8816@mail.unnes.ac.id 


\section{PENDAHULUAN}

Lingkungan sekolah merupakan salah satu hal yang mampu mendukung proses pembelajaran menjadi maksimal. Selain itu juga bisa untuk tempat yang nyaman ketika masyarakat sekolah ingin melakukan aktivitas positif diluar proses pembelajaran. Seperti yang disampaikan Ahmad dalam Latief (2014: 262) lingkungan adalah ruang dan waktu yang menjadi tempat eksistensi manusia. Baik buruknya lingkungan di sekitar anak merupakan faktor utama yang mempengaruhi perkembangan jiwa dan keberhasilan hasil belajar anak (peserta didik). Lingkungan tersebut adalah lingkungan sekolah, keluarga dan masyarakat. Sayangnya lingkungan di SDN Patemon 2 masih belum diberayakan secara maksimal. Yaitu dengan masih banyaknya lahan kosong. Maka dari itu tim pengabdi dengan mitra berencana mengubah lingkungan sekolah yang masih belum diberdayakan menjadi lebih bermanfaat dalam mendukung pembelajaran.

Beberapa fungsi lingkungan yang disampaikan oleh Latief 2014 adalah terdiri dari tiga fungsi, yaitu fungsi psikologis, fungsi pedagogis dan fungsi insruksional. Dimana kegiatan yang akan dilakukan tim pengabdi adalah dengan mendukung fungsi lingkungan dengan merubah lingkungan yang masih kosong belum diberdayakan menjadi lingkungan yang ramah anak, indah dan nyaman demi mendukung proses pembelajaran menjadi lebih maksimal. Selain itu sesuai dengan tujuan UNNES yaitu tekait dengan konservasi peduli lingkungan. Dimana dengan penataan lingkungan sekolah diharapkan mampu untuk menumbuhkan rasa cinta peduli terhadap lingkungan bagi seluruh masyarakat sekolah.

Setiap perguruan tinggi dituntut untuk melaksanakan Tri Dharma Perguruan Tinggi, yaitu: Pendidikan dan Pengajaran, Penelitian dan Pengembangan, serta Pengabdian terhadap masyarakat. Begitu juga dengan UNNES. Sebagai bentuk dari Tri Dharma ketiga tersebut, tim pengabdian Prodi Pendidikan IPS Fakultas Ilmu Sosial Universitas Negeri Semaranga ingin melakukan kegiatan penataan lingkungan sekolah dalam mendukung proses pembelajaran.
Dalam hal ini, tim pengabdian melaksanakan pengabdian masyarakat tentang Pemberdayaan Lingkungan Sekolah. Jadi masalah pokok yang akan dikaji alam kegiatan pengabdian kepada masyarakat sebagai berikut: bagaimanakah Penataan Lingkungan SDN Patemon 2 Sebagai Wujud Konservasi Peduli Lingkungan?

\section{METODE}

Pengabdian ini akan dilaksanakan di SDN Patemon 2 Kelurahan Patemon Kecamatan Gunungpati Kota Semarang. Pengabdian ini diawali dengan menemukan masalah kemudian menawarkan solusi dari permasalahan yang ada dan melakukan kegiatan Penataan Lingkungan SDN Patemon 2 Sebagai Wujud Konservasi Peduli Lingkungan.

Khalayak sasaran dalam pengabdian ini yaitu warga sekolah dikhususkan untuk kelas 2 SDN Patemon 2, Kelurahan Patemon Kecamatan Gunungpati Semarang. Prosedur kerja dalam pengabdian kepada masyarakat dengan judul Penataan Lingkungan SDN Patemon 2 Sebagai Wujud Konservasi Peduli Lingkungan antara lain: perencanaan kegiatan PPM, pelaksanaan kegiatan PPM dan evaluasi kegiatan PPM.

\section{HASIL DAN PEMBAHASAN}

\section{A. Perencanaan Kegiatan Pengabdian.}

1. Studi lapangan mengenai permasalahan mitra pengabdian.

Sesuai yang sudah disampaikan saat pengajuan kegiatan pengabdian pada masyarakat mengenai penataan lingkungan di SDN Patemon 2 ini. Terkait dengan kondisi sekolah yang memang memiliki lahan luas tetapi belums epenuhnya digunakan untuk kepentingan sekolah, terutama untuk menunjangs ekolah ramah anak, baik ramah dalam proses pembelajaran maupun ramah diluar proses pembelajaran. Maka tim pengabdi berusaha bersama-sama dengan mitra untuk melakukan penataan lingkungan sekolah SDN 
Patemon 2, sehingga mampu untuk mendukung proses pembelajaran di dalam dan luar ruangan.

Hal lain yang masih menjadi skala prioritas mengenai permasalahan mitra, selain adalnya lahan yang belum dioptimalkan adalah terkait dengan pemahaman mitra mengenai pentingnya penataan lingkungan dalam mendukung proses pembelajaran. Bukan hanya itu, mitra juga masih bingung bagaimana caranya untuk menata lingkungan. Supaya mitra lebih paham maka tim pengabdi bersama-sama dengan mitra dan bahkan peserta didik melakukan penataan lingkungan SDN Patemon 2.

\section{Penyusunan strategi Penataan Lingkungan SDN Patemon 2 Sebagai Wujud Konservasi Peduli Lingkungan.}

Strategi dalam penataan lingkungan SDN Patemon 2 adalah dengan mengikutsertakan mitra dalam pelaksanaannya. Baik wali murid, guru kelas maupun peserta didik. Dalam hal ini karena lingkungan sekolah SDN Patemon 2 sangat luas sekali, maka tim pengabdi mengelola penataan lingkungan sedikit demi sedikit. Dalam hal ini mitra yang diajak bersama-sama menata lingkungan adalah peserta didik kelas 2 , guru kelas 2 dan wali murid peserta didik kelas 2. Jadi antara mitra dan tim pengabdi sudah sepakat untuk melakukan kegiatan penataan lingkungan SDN Patemon 2 dengan pastinya diawali dengan memahamkan maksud dan tujuan kepada mitra. Dan Alhamdulillah mitrapun mengerti dan paham akan pentingnya penataan lingkungan SDN Patemon 2.

\section{B. Pelaksanaan.}

1. Menjelaskan tentang Penataan Lingkungan SDN Patemon 2 Sebagai Wujud Konservasi Peduli Lingkungan.

Kegiatan ini dilakukan dengan kondisi terbatas, dikarenakan kondisi yang masih belum normal. Kita masih dalam Pandemi Covid-19. Maka dari itu kegiatan dalam memahamkan kembali akan pentingnya Penataan Lingkungan SDN Patemon 2 sebagai wujud konservasi peduli lingkungan dilakukan dalam WAG "Wali Murid SD Patemon 2". Dalam WAG tersebut sisampaikanlah hal-hal terkait dengan penataan lingkungan SDN Patemnon 2. Dan Alhamdulillah mendapat respon positif dari wali murid mengenai pentingnya penatan lingkungan. Bahkan mereka malah menawarkan diri bagaimana jka saat membeli tanaman untuk menata lingkungan mereka ikut serta, bukan hanya saat menata lingkungan saja.

Penataan lingkungan SDN Patemon 2 ini diharapkan mampu untuk meningkatkan rasa sayang pada lingkungan, sehingga muncul kepedualian untuk selalu menjaganya. Sekolah merupakan salah satu lembaga pendidikan formal. Kegiatan utama di lembaga ini adalah proses belajar dan mengajar (PBM). Keberhasilan PBM dipengaruhi oleh banyak komponen, dia antaranya guru, kurikulum, sarana dan prasarana pendukung, dan lain sebagainya. Adalah wajar jika proses dan hasil PBM menjadi salah satu indikator kualitas sekolah. Jika proses pembelajaran itu berkualitas, asumsinya hasil pembelajaran juga akan optimal. Tentu saja, proses dan hasil yang bermutu tidak saja tergantung pada komponen yang disebut di atas. Ada kondisi lain yang mendukung terwujudnya pembelajaran berkualitas tersebut. Salah satunya adalah suasana lingkungan belajar yang kondusif. Barangkali, betapapun hebatnya guru mengajar, bagusnya kurikulum pendidikan dan lengkapnya sarana dan prasarana belajar. Belum berarti banyak jika tidak didukung oleh lingkungan sekolah yang nyaman dan kondusif.

Lingkungan belajar, khususnya lingkungan fisik berpengaruh besar terhadap pelaksanaan PBM di sekolah. Suasana yang nyaman lagi menyenangkan akan mendukung proses belajar secara optimal. Suasana ini berasal dari lingkungan yang bersih, segar dan asri. Salah satunya adalah dengan penataan lingkungan sekolah dengan membuat taman yang indah. Penataan lingkungan sekolah yang baik akan membuat warga sekolah betah berada di sekolah. Penataan itu antara lain; taman kelas dan taman sekolah, penataan lapangan upacara, koridor kelas dan fasilitas belajar, dan penataan warna dinding setiap unit gedung belajar. 
2. Pendampingan implementasi Penataan

Lingkungan SDN Patemon 2 Sebagai Wujud Konservasi Peduli Lingkungan.

a) Pemilihan tanaman hias

Kegiatan pendampingan ini dilakukan tim pengabdi supaya antara mitra dan tim pengabdi bisa saling tukar pendapat baiknya seperti apa, supaya lingkungan sekolah saat ditata akan lebih menarik, cepat selesai dan bisa bermanfaat untuk semua warga sekolah. Kegiatan pertama dalam pelaksanaan adalah dengan melakukan pemilihan tanaman hias yang akan ditata dalam lingkungan SDN Patemon 2.

Kegiatan pemilihan tanaman untuk penataan lingkungan SDN Patemon 2, dilakukan dengan mengajak paguyuban wali murid kelas 2. Tujuannya adalah supaya kegiatan ini selain bisa untuk menumbuhkan sikap peduli lingkungan, mendukung pembelajaran maksimal, juga menjalin kerjasama dan tali silaturahmi yang lebih dengan mitra. Selain itu, masukkan dari paguyuban merupakan hal yang tak kalah penting dalam menunjang penataan lingkungan SDN Patemon 2.

Bukan hanya paguyuban wali murid saja yang memberikan amsukan untuk tanaman yang akan dieksekusi dalam penataan lingkungan SDN patemon 2. Tim pengabdi juga memberikan masukkan terkait dengan tanamantanaman yang cocok ditanam dalam lingkungan sekolah dan tidak membahayakan.

\section{b) Penataan lingkungan SDN Patemon 2 dengan pembuatan taman ramah anak.}

Kegiatan kedua dalam pelaksanaan adalah terkait dengan penataan lingkungan SDN patemon 2 dengan pembuatan taman ramah anak. Kegiatan ini dilakukan dengan menyiapkan tanaman hias, alat dan bahan lainnya kemudian bersama-sama baik mitra maupun tim pengabdi melakukan penataan.

Penataan lingkungan dilakukan bersamasama dengan mitra, khususnya dengan peguyuban wali murid SDN Patemon 2 kelas 2 . Wali murid antusias sekali dalam penataan lingkungan. Bahkan ada beberapa wali murid yang dengan sengaja dan ikhlas membawa tanaman hias dari rumah untuk menambah keindahan dan kenyamanan lingkungan SDN Patemon 2 yang sedang ditata. Hal ini membuktikan bahwa sebenarnya wali murid juga memiliki perhatian yang luar biasa terhadap kepedulian lingkungan dan anaknya yang bersekolah di SDN Patemon 2, kembali lagi untuk kenyamanan bersama.

Mitra dan tim pengabdi merasa puas dengan hasilnya. Dan kami anggap ini masih belum berhasil sepenuhnya. Karena penataan into tetap akan selalu berjalan. Tahap selanjutnya adalah dengan tetap berkomunikasi dengan mitra untuk pemeliharaannya. Dan Alhamdulillah pihak paguyuban wali kelas 2 (dalam hal ini mitra) bersedia untuk menjaga taman yang sudah ditata dengan indah. Bahkan mereka melanjutkan untuk membuat jadwal pemeliharaan tanaman. Yaitu dengan mencabuti rumput liar dan menyiram tanaman seperlunya.

\section{Evaluasi Hasil Pelaksanaan Pengabdian.}

Tim pengabdian kepada masyarakat mengevaluasi hasil pengabdian. Dlaam hal ini pengabdian dikatakan selesai terkait dengan penataan lingkungan SDN Patemon 2 sebagai upaya mewujudkan konservasi peduli lingkungan. Walaupun belum maksimal tetapi Alhamdulillah bisa terlaksana dengan baik. Dengan kegiatan ini baik mitra dan tim pengabdi diharapkan akan lebih meningkatkan wujud konservasi peduli lingkungan.

\section{SIMPULAN}

Kesimpulan yang dapat tim penelitinambil dari kegiatan Penataan Lingkungan SDN Patemon 2 sebagai Wujud Konservasi Peduli Lingkungan adalah sebagai berikut.

1. Kegiatan pengabdian pada masyarakat mengenai Penataan Lingkungan SDN Patemon 2 sebagai Wujud Konservasi Peduli Lingkungan merupakan solusi yang tepat dalam memecahkan masalah yang dialami SDN patmon 2 yang memiliki lingkungan luas yang belum dimanfaatkan sebagaimana mestinya. 
2. Kegiatan pengabdian pada masyarakat ini meliputi kegiatan pembekalan/penyuluhan mengenai pentingnya Penataan Lingkungan SDN Patemon 2 sebagai Wujud Konservasi Peduli Lingkungan, pendampingan Penataan Lingkungan SDN Patemon 2 sebagai Wujud Konservasi Peduli Lingkungan dan evaluasi Penataan Lingkungan SDN Patemon 2 sebagai Wujud Konservasi Peduli Lingkungan dengan mendapat tanggapan dan antusiasn yang luar biasa baik dari mitra, yaitu baik dari paguyuban wali murid kelas 2 maupun warga sekolah SDN Patemon 2.

3. Adanya Penataan Lingkungan SDN Patemon 2 sebagai Wujud Konservasi Peduli Lingkungan diharapkan ini dapat mendukung proses pembelajaran menjadi lebih baik lagi, dan membuat suasana nyaman dalam lingkungan sekolah.

\section{DAFTAR PUSTAKA}

Hasbullah. (2009). Dasar-dasar Ilmu Pendidikan. Jakarta: Rajawali Pers.

Latief, Abul. (2014). Pengaruh Lingkungan Sekolah terhadap Hasil Belajar Pendikan Kewarganegaraan pada Peserta didik di SMK Negeri Paku Kecamatan Binuang Kabupaten Polewari Mandar. Jurnal Pepatuzdu, Vol.7 No.1 Mei 2014.

Panduan Pengabdian Pada Masyarakat Fakultas Ilmu Sosial Universitas Negeri Semarang 2020. 